\title{
A longitudinal study of zooplankton along the Lower Orinoco River and its Delta (Venezuela)
}

\author{
E. Vásquez' \\ J. Rey²
}

Keywords : Orinoco River, Orinoco Delta, zooplankton abundance, zooplankton composition

Zooplankton samples collected at low and high water in 14 and 21 stations respectively along some $900 \mathrm{~km}$ of the Orinoco and its Delta, revealed the presence of 100 rotifer and 48 cladoceran taxa. Of these, only 13 rotifer and 8 cladoceran species were frequent and numerically important, mainly Keratella americana, Lecane proiecta, Ploesoma lenticulare, Polyarthra vulgaris, Bosmina tubicen, Bosminopsis deitersi, Diaphanosoma birgei and Moina minuta. Nauplii were dominant among the copepods. At low water, rotifers were by far the most abundant group (mean $49 \mathrm{org} . / 1$ ) followed by cladocerans (mean $2.8 \mathrm{org} / \mathrm{l}$ ) and copepods $(1.5 \mathrm{org} / \mathrm{l})$. At high water, rotifer densities declined to a mean of $3,5 \mathrm{org} / \mathrm{l}$, followed by copepods (mean $3.4 \mathrm{org} /$ ) and cladocerans (1.2 org/l). Mean zooplankton densities at low water were eight times higher than at high water. At low water, longitudinal zooplankton densities seemed to be influenced by tributary river waters. At high water, densities were generally low up to the Delta where a longitudinal increase was observed. A high proportion of egg carrying cladocerans, particularly B. tubicen, B. deitersi and $M$. minuta, were observed at low water along the sampling sites, suggesting an ability of the species for growth and reproduction in the river.

Etude longitudinale du zooplancton du Bas Orénoque et de son Delta (Vénézuela)

Mors clés : Fleuve Orénoque, Delta Orénoque, zooplancton, abondance, composition.

L'étude longitudinale de l'abondance et de la composition du zooplancton, en période de basses et de hautes eaux dans 14 et 21 stations respectivement de l'Orénoque et de son Delta, a révélé la présence de 100 taxa de rotifères et de 48 taxa de cladocères. Seuls 13 rotifères et 8 cladocères sont fréquents et numériquement importants : principalement Keratella americana, Lecane proiecta, Ploesoma lenticulare, Polyarthra vitgaris, Bosmina tubicen, Bosminupsis deitersi, Diaphanosuma birgei et Moina minuta. Les copépodes sont essentiellement représentés par des nauplii. A basses eaux, les rotifères constituent le groupe le plus abondant ( $49 \mathrm{org} / \mathrm{l}$ en moyenne), suivi par les cladocères ( $2.8 \mathrm{org} / \mathrm{len}$ moyenne) et les copépodes (1.5 org/l). A hautes eaux. les rotifères chutent à $3.5 \mathrm{org} / \mathrm{l}$ en moyenne, suivis par les copépodes (moyenne : $3.4 \mathrm{org} / \mathrm{l}$ ) tt les cladocères (1.2 org/l). La densité moyenne du zooplancton est diminuée d'un facteur 8 à hautes eaux. Longitudinalement, à basses eaux, l'abondance du zooplancton semble être influencée par les eaux des tributaires. A hautes eaux, les densités sont généralement faibles jusqu'au Delta où l'on observe un accroissement longitudinal. Une forte proportion de cladocères ovigères, principalement $B$. tubicen, $B$. deitersi et $M$. minufa, observés à basses eaux tout au long des sites cchantillonnés, semble indiquer que ces populations peuvent se reproduire et se développer dans le fleuve.

\section{Introduction}

Hynes (1970) and Welcomme (1985) have pointed out the scarcity of zooplankton studies from tropical rivers. The study of these communities from Venezuelan rivers of the Orinoco Basin has recently received much attention. This interest stems from

1. Fundacion La Salle de Ciencias Naturales, Estación Hidro biulógica de Guayana, Apdo. 51, San Félix, Edo. Bolivar, Verezuela.

2. Laboratoire d'Hydrobiologie, Université Paul-Sabatier, UA 695 du CNRS, 118, route de Narbonne, 31062 Toulouse Cédex. France. the fact that these rivers are, in most cases, tropical watercourses with no or scarce human intervention. Similarly, the study of zooplankton from these rivers offers the opportunity to study the interactions established between the watercourses and their floodplains.

The first study which included analysis of zooplankton collected in the Orinoco floodplain was that of Hauer (1956). More recent studies include those of Vásquez \& Sánchez (1984) who studied plankton from the Lower Orinoco and an adjacent floodplain 
lake and Saunders \& Lewis (1989) who carried out an extensive study of zooplankton from the Lower Orinoco and some tributaries. Vásquez (1984 a) and Rey \& Vásquez (1986 a) carried out taxonomic studies of rotifers and cladocerans from the Lower Orinoco and some of its tributaries and floodplain lakes. Dussart (1984) studied copepods from different lotic and lentic habitats of the basin.

Zooplankton from the major tributaries of the Orinoco has been studied by Vásquez ( 1984 b) (Caroni River), and Saunders \& Lewis (1988 a, b), (Caura and Apure rivers). Other minor tributaries were studied by Sánchez \& al. (1985). Information generated so far has been valuable to establish seasonal patterns of abundance, composition and biomass. This information may also be of value to establish comparisons with other neotropical floodplain rivers such as the Amazon and the Parana where river zooplankton is well documented (José de Paggi 1978, 1983, Robertson \& Hardy 1984).

The present study was carried out to survey the longitudinal abundance and composition of zooplankton along the mainstream of the Orinoco River, margins of the river channel and some of the Orinoco distributaries in the Delta region.

\section{Study Area}

The Orinoco Basin drains a surface of $1.1 \times 10^{6} \mathrm{~km}^{2}$ shared by Venezuela (70\%) and Colombia (30\%) (Fig. 1). From the north and west, the Orinoco receives the waters of rivers draining the Venezuelan and Colombian Andes as well as the alluvial plains of the Llanos located between the Andes and the Guayana Shield. Rivers draining from this portion of the watershed contribute the greatest quantity of sediments transported by the Orinoco for which they are usually referred to as whitewater rivers. They also present high amounts of electrolytes (Meade et al 1983). From the south, the Orinoco receives primarily blackwaters of rivers draining the Guayana Shield which consists of lithologically complex Precambrian rocks (Gibbs \& Barron 1983). Blackwaters are characterized by a very low content of nut rients and dark color caused by a high content of dissolved organic matter. Electrolyte content may also be low (Vegas-Vilarrúbia et al 1988). This group of blackwater rivers includes the most important watercourses of the basin with regard to length and average annual discharge. Within this group the Caroni constitutes the only major river regulated in the watershed.

Worlwide the Orinoco ranks third in terms of average water discharge $\left(36000 \mathrm{~m}^{3} / \mathrm{s}\right)$ and its suspended load has been estimated at $200 \times 10^{\circ}$ tons/year (Meade et al. 1983). $73 \%$ of the Orinoco flow reaching its mouth originates from the basin above the Apure River. This river contributes $7 \%$ of the Orinoco flow while the Caura and Caroni rivers contribute $9 \%$ and $11 \%$ respectively (Lewis 1988). Over most of its $2060 \mathrm{~km}$ length the Orinoco flows through lowlands forming a braided course with banks and islands. In the lower Orinoco slope is weack, water velo city is slow (1-2 m/s) and flow is high (M.A.R.N.R. 1979).

The hydrological regime of the basin belongs to the contrasted type with a high water phase extending from May to November. Minimum water level generally occurs in late April or early May (Fig. 2). The narrow fringing floodplain of the Orinoco presents numerous temporary and permanent floodplain lakes of various sizes and shapes (Vásquez 1988).

The Orinoco Delta is situated between the northern cuastal range of Venezucla and the Guayana Shield margin to the south, with an expanse of some $22500 \mathrm{~km}^{2}$. The deltaic plain is formed by very low lands (slope $<1 \%$ and elevation a.s.l. $<10 \mathrm{~m}$ ). This region is drained by 9 major dis. tributaries and many interconnecting smaller canals, all of which are locally known as " caños ", resulting in numerous islands and temporary and permanent lakes ivan Andel 1967, M.A.R.N.R. 1979). Measured from the apex of the Del ta the major caños are : Rio Grande $(270 \mathrm{~km})$, Macareo $(211 \mathrm{~km})$, and Mánamo $(236 \mathrm{~km})$. As a distributary the Rio Grande discharges $84 \%$ of the Orinoco llow. Van Andel (1967) considers that tidal range in the Delta is relatively small compared to differences between high and low waters of the river. At high water the Delta is almost completely flooded. Wilbert (1986) divided the Orinoco Delta into a prelittoral zone, covering the region near the apex with a mcan elevation of $34 \mathrm{~m}$.a.s.l.; a littoral zone (10-30 km wide) which comprises a coastal strip of mangrove forest, palm forest, and savannas permanently flooded by tidal waters ; and an intermediate zone, wedged between the previous two and under the influence of the tides.

\section{Methods}

Zooplankton samples were collected at high water (18-26 September 1985) and low water (3-10 April 1986).

- At high water, collections were rnade al 21 sampling sites (Fig. 1), within an approximate strech of $900 \mathrm{~km}$.

- At low water, samples were collected in 14 sampling sites within a strech of some $750 \mathrm{~km}$.

In 9 of these sites located between Samariapo and the apex of the Delta, collections were made in the middle of the river and in its two shores. In the Delta, collections were taken only in the middle (Table I). At each site, 80 liters of subsurface water was collected and filtered through a $45 \mu \mathrm{m}$ mesh net. For rotifers and copepods $5 \mathrm{ml}$ subsamples were examined; they generally allowed the identification of at least 100 of the most abundant taxa. In cases of low density the entire sample was examined. However, for cladocerans, the entire sample was always counted. Rotifers and crustaceans demanding detailed taxonomic studies were mounted in polyvinil alcohol and glicerine alcohol, respectively. 


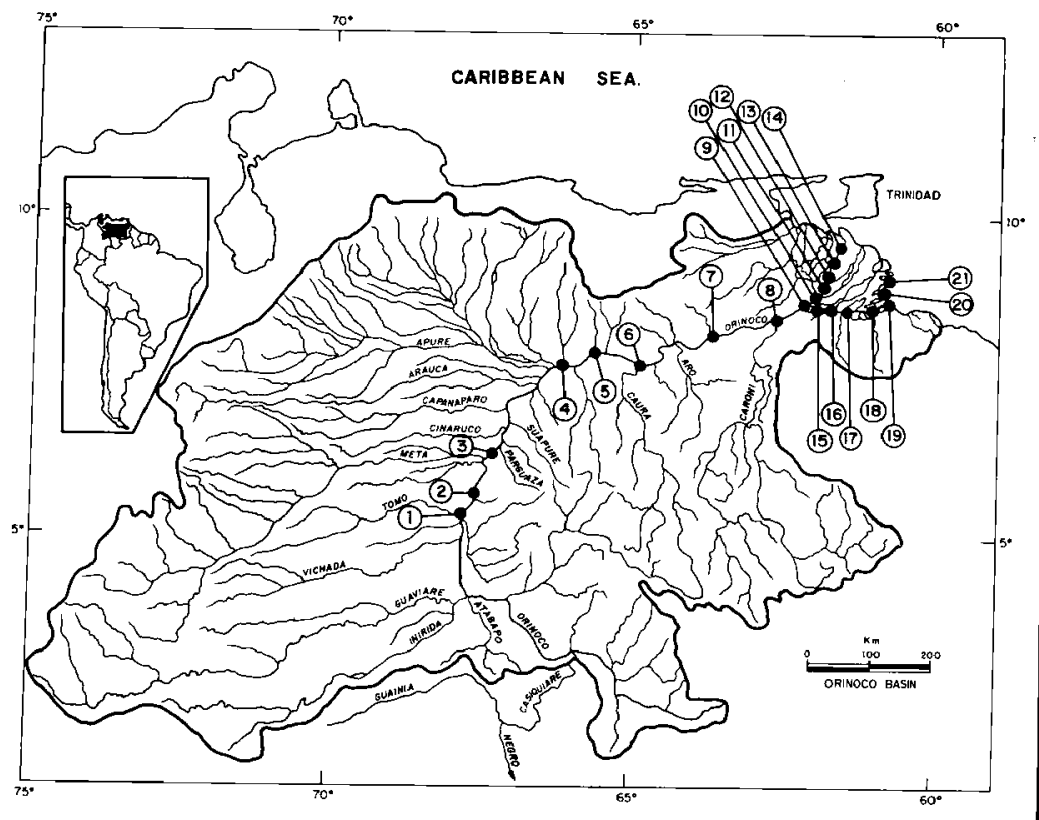

Fig. 1. The Orinoco River Basin and location of sampling sites.

Table I. Nurnber and name of sampling sites and number of samples collected.

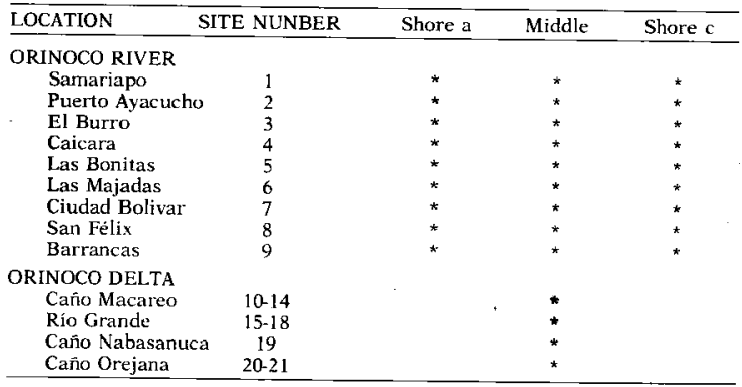




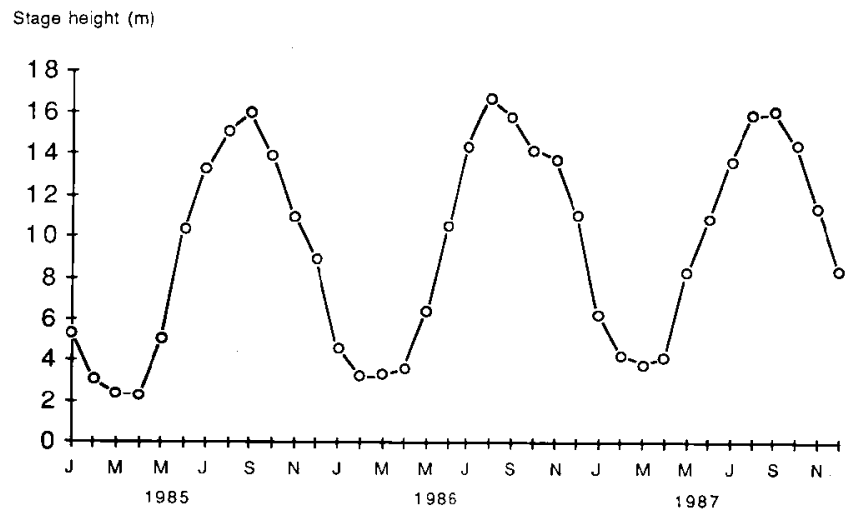

Fig. 2. Stage height in the Orinoco River (Angostura), (1985-1987).

\section{Results and Discussion}

\subsection{Zooplankton composition}

In this paper, copepods are considered as a whole. The inventory of rotifers and cladocerans are reported in Table II.

100 rotifer taxa were identified out of which $25 \%$ belong to the genus Brachionus, $22 \%$ to Lecane, and $15 \%$ to Trichocerca. Over $50 \%$ of the identified organisms were planktonic or semiplank tonic species. 13 rotifer species are new records for Venezuela. The record and description of $B$. variabilis was published elsewhere (Vásquez \& Koste 1988). Other new brachionids for the country include $B$. bidentata bidentata, $B$. catdatus vulgatus, and $B$. diversicornis diversicomis. Lecane lunaris perplexa was firstly recorded in South America by José de Paggi \& Koste (1988) in the Saladillo River Basin. The presence of this species in the Orinoco supports the observations of these authors who consider that the Paraná River carries southwards fauna of tropical or subtropical origin therefore extending the Guyana-Brazilian subregion further to the south. Lecane amazoniana had previously been recorded from Brazil, Paraguay, and Argentina (José de Paggi \& Koste 1988). Ploesoma lenticulare, an abundant species in our samples, was previously found in South America in Brazil and Argentina (Hauer 1965, Paggi \& José de Paggi 1973).

Concerning cladocerans 48 taxa were identified : $45.8 \%$ were Chydoridae, $16.7 \%$ Sididae, $12.5 \%$ Daphniidae, $10.4 \%$ Bosminidae, $8.3 \%$ Macrothricidae, and $6.3 \%$ Moinidae. The number of cladocerans found in the Orinoco was higher than that reported for the Paraná (José de Paggi 1980) as well as for African rivers such as the Sokoto (Green 1962), the Oshun (Egborge 1972) and the Warri (Egborge 1987).

Among cladocerans, Bosminopsis brandorffi (a new species described by Rey et Vásquez 1989) collected from the Nhamunda River in the Amazon (Brandorff et al. 1982), was present in many sampling sites of the Orinoco. Diaphanosoma volzi, a rare form, only reported from Thailand, China, Australia (Korovchinsky 1981] was observed at site 1 , at low water. Diaphanosoma polyspina (from Amazon Basin) was again recorded in the Orinoco. Bosminopsis negrensis was observed at high water from samples collected at site 3 (El Burro). Described by 


\section{ROTIFERA}

Anuraeopsis fissa fissa

Anuraeopsis navicula navicula

Asplanchna brightwelli

Asplanchna sieboldi

Bdelloidae ind.

Brachionus angularis pseudolabratus

Brachionus bidentata

Brachionus budapestinensis

Brachionus calyciflorus f. amphiceros

Brachionus calyciflorus calyciflorus

Brachionus caudatus austrogenitus

Brachionus caudatus caudatus

Brachionus caudatus f. insuetus

Brachionus caudatus f. personatus

Brachionus caudatus vulgatus

Brachionus diversicornis diversicornis

Brachionus dolabratus

Brachionus falcatus falcatus

Brachionus forficula

Brachionus gessneri

Brachionus gillardi

Brachionus havanensis

Brachionus mirus f. angustus

Brachionus patulus macracanthus

Brachionus patulus patulus

Brachionus quadridentatus quadridentatus

Brachionus rubens

Brachionus urceolaris urceolaris

Brachionus variabilis

Brachionus voigti

Cephalodella mucronata

Collotheca sp.

Collotheca campanulata campanulata

Colurella sp.

Conochilus dossuarius dossuarius

Epiphanes macrourus

Euchlanis dilatata dilatata

Euchlanis meneta

Filinia longiseta limnetica

Filinia longiseta longiseta

Filinia opoliensis

Filinia pejleri pejleri

Hexarthra intermedia brasiliensis

Hexarthra intermedia intcrmedia

Keratella americana

Keratella cochlearis cochlearis

Keratella lenzi lenzi

Keratella tropica tropica

Lecane sp.

Lecane aegana
Lecane amazoniana

Lecane bulla bulla

Lecane bulla styrax

Lecane cornuta cornuta

Lecane curvicornis curvicornis

Lecane hastata

Lecane hornemanni

Lecane leontina leontina

Lecane levistyla levistyla

Lecane ludwigi ludwigi

Lecane luna luna

Lecane lunaris lunaris

Lecane lunaris perplcxa

Lecane melini

Lecane papuana

Lecane proiecta

Lecane rhenana

Lecane signifera ploenensis

Lecane stichaea stichaea

Lecane ungulata ungulata

Lepadella patella f. oblonga

Lepadella patella patella

Macrochaetus collinsi collinsi

Monommata sp.

Mytilina ventralis macracantha

Platyias quadricornis quadricormis

Ploesoma lenticulare

Polyarthra remata

Polyarthra vulgaris vulgaris.

Ptygura sp.

Synchaeta sp.

Testudinella mucronata hauerensis

Testudinella ohlei ohlei

Testudinella patina dendradena

Testudinella patina patina

Testudinella tridentata amazonica

Trichocerca sp.

Trichocerca bicristata bicristata

Trichocerca capucina capucina

Trichocerca chattoni

Trichocerca elongata elongata

Trichocerca flagellata

Trichocerca gracilis

Trichocerca inermis

Trichocerca pusilla

Trichocerca ruttneri

Trichocerca similis grandis

Trichocerca similis similis

Trichocerca stylata

Trichotria tetractis tetractis 
Table II. (suite)

CLADOCERA
Alona sp.
Alona eximia
Alona guttata
Alona monacantha
Alona poppei
Alona quadrangularis
Alona rustica
Biapertura sp.
Biapertura intermedia
Biapertura verrucosa
Bosmina hagmanni
Bosmina t bicen
Bosminopsis brandon66i n.sp.
Bosminopsis deitersi
Bosminopsis negrensis
Camptocercus sp.
Ceriodaphnia cornuta
Chydorus sp.
Chydorus eurynotus
Chydorus nitidulus
Daphnia gessneri
Dadaya macrops
Diaphanosoma sp.1
Diaphanosoma sp. 2

Diaphanosoma birgei
Diaphanosoma brevireme
Diaphanosoma polyspina
Diaphanosoma spinulosum
Diaphanosoma volzi
Disparalona dadayi
Echinisca sp.
Echinisca triserialis
Ephemeroporus hybridus
Ephemeroporus tridentatus
Euryalona occidentalis
Graptoleberis testudinaria
lyocryptus spinifer
Latonopsis australis
Macrothrix spinosa.
Moina micrura
Moina minuta
Moina reticulata
Notoalona globulosa
Oxyurella sp.
Pseudosida bidentata
Scapholeberis sp.
Scapholeberis kingi
Simocephalus serrulatus

Brandorff (1976) from material collected in the Amazone, B. negrensis was firstly recorded for Venezuela by F. Weibezahn (pers. comm.). E. Zoppi de Roa (pers. comm.) has collected but not reported $B$. negrensis from the mouth of the Atabapo River, a blackwater tributary of the Orinoco. Based upon the previous findings, the distribution range of the species is enlarged to include the Orinoco Basin to the Amazon (Weibezahn et al, in press).

Interesting to note in the samples was the presence of Daphnia gessneri observed at site 2 (Puerto Ayacucho) at low water (density 0.01 org./). This specres had been reported for reservoirs in the Caroni River (Infante 1984, Rey \& Vásquez 1986 a) and this was the first time that it was observed in the Orinoco waters. In contrast with the Amazon where this species is frequent and sometimes abundant in reservoirs and floodplain lakes (Arcifa 1984,
Robertson \& Hardy 1984), in the Orinoco system $D$. gessneri is rare and scarce.

Mean rotifer species richness (Fig. 3) was 7.2 at high water and increased to 22.9 at low water. Mean number of cladoceran species was 4.2 and 5.4 at high and low water respectively (Fig. 4.).

Longitudinally, rotifer species richness at high water was higher in the Delta than in the Orinoco. At low water, the number of species was relatively similar along the sites. Number of species of cladocerans at both high and low water, was highest in the river.

\subsection{Overall zooplankton density}

- At high water, mean zooplankton density (Fig. 5 a) was $5.6 \mathrm{org} . /$ along shore a, $2.1 \mathrm{org} . / \mathrm{l}$ along shore c. Mean density in the middle of the river and in Cano Macareo was $12.6 \mathrm{org} . / \mathrm{l}$. 

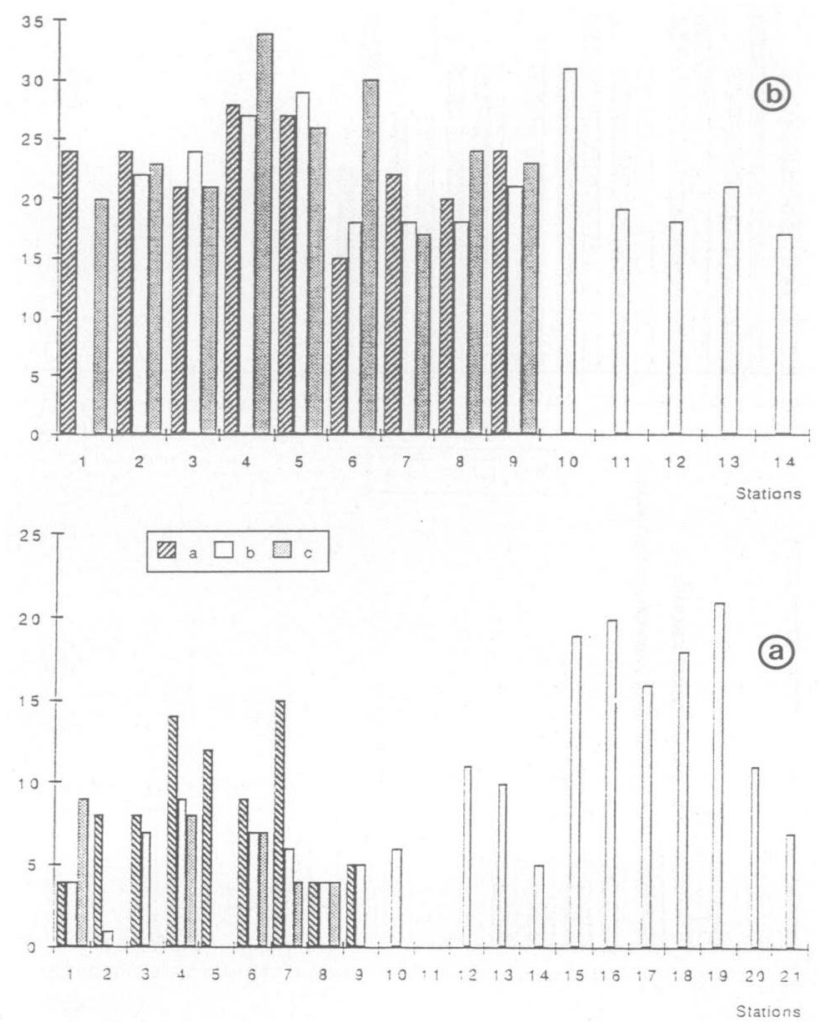

Fig. 3. Rotifer species richness at high water (a) and low water (b). 

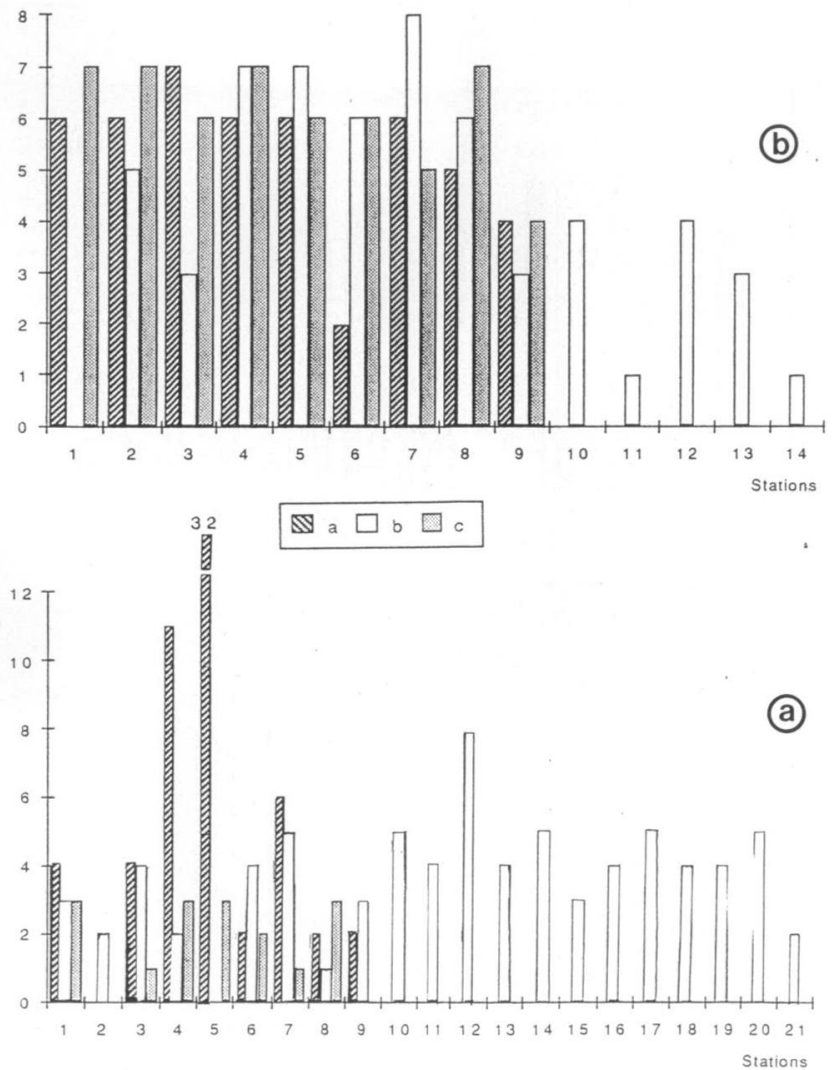

Fig. 4. Cladoceran species richness at high water (a) and low water (b). 

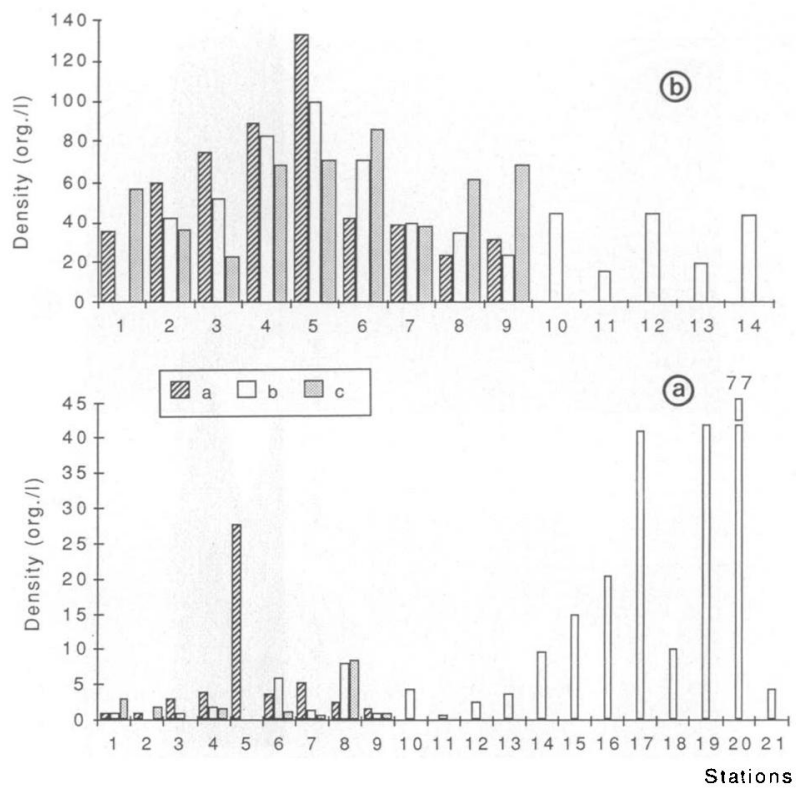

Fig. 5. Zooplankton density at high water (a) and low water (b).

- At low water, zooplankton density showed a marked increase with a mean of 59.1 org./l along shore a, 56.9 along shore $c$ and 47.5 along the middle sites (Fig. 5 b) : a mean density eight time higher than at high water.

An inverse relationship between discharge and plankton density in the Orinoco had previously been reported (Vásquez \& Sánchez 1984, Saunders \& Lewis 1989). The results also indicate that, particularly at low water, densities along the shores were not markedly different from middle sites in spite of the fact that these riverine sites may present more favorable conditions for zooplankton growth. A similar observation was reported by José de Paggi (1980,
1981) who pointed out a fairly homogeneous horizontal distribution of zooplankton in the Paraná River and in some of its tributaries.

Considering each zooplankton group separately, at high water, rotifer abundance showed a mean of $3.5 \mathrm{org} . / 1(43.1 \%)$ followed by copepods (mean $3.4 \mathrm{org} . / 1 ; 1.8 \%)$ and cladocerans $(1.2 \mathrm{org} . /$; $15.1 \%$ ) (Fig. 6 a). At low water rotifers were by far the most abundant zooplankton group with a mean density of $49 \mathrm{org} . /$ ( $(92 \%$ ) followed by cladocerans ( $2.8 \mathrm{org} . / \mathrm{l} ; 5.2 \%$ ), and copepods ( $1.5 \mathrm{org} . / 1 ; 2.8 \%$ ) (Fig. 6 b). At both high and low water, copepod abundance was primarily due to nauplii stages. 


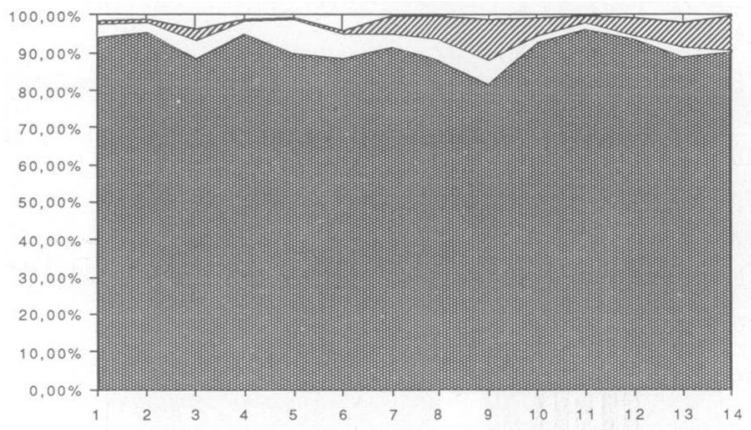

(b)

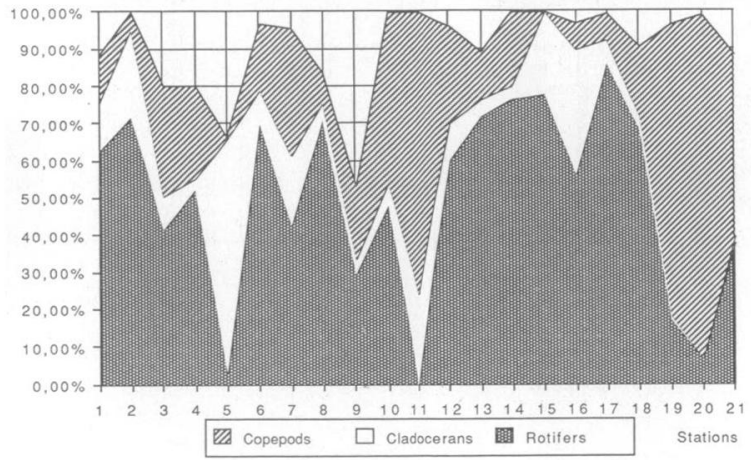

Fig. 6. Relative density of copepods, cladocerans and rotifers at high water (a) and low water (b).

\subsection{Longitudinal patterns of density}

\section{a) Overall zooplankton}

- At high water (Fig. 5 a), at all river sites, the longitudinal distribution of zooplankton did not show a defined pattern of abundanec. The density of organisms was low except in site 5 (shore a) where a high density was observed (mainly cladocerans such as Bosminopsis deitersi, Bosmina hagmanni.
Ceriodaphnia cornuta, many Chydoridae, and insect larvae). On the contrary in the Delta region, the zooplankton density was higher than that observed in the Orinoco, with a marked tendency to increase along the distributaries, probably due to organisms flushed from the vast flooded areas to the canos. In this period, zooplankton groups showed uscillations in their relative densities along the water-courses. Rotifers, however, were more abundant in most of 
the sites except in site 5 where, as mentioned, cladocerans prevailed the other groups, and in sites 11 , $19,20,21$ in the Delta, where copepods (nauplii) represent $70 \%$ to $90 \%$ of the zooplankton (Fig. 6 a).

In this period appeared also drifting organisms such as insect larvae, nematodes, and others, very scarce at low water, and which were present in the samples as the result of being flushed into the mainstream flow from the river buttom and other floodplain areas.

- At low water (Fig. 5 b), zooplankton abundance along shore $a$ and in the middle of the river increased longitudinally in the stretch between sites 1-5 and then decreased up to the apex of the Delta (site 9). In Cano Macareo (sites 10-14) there was a slight oscillating increase in abundance without a clear pattern. Decrease in abundance observed at sites 6 and 8 was probably due to the dilution effect produced by the blackwaters of the Caura and Caroni Rivers. In both these rivers, zooplankton abundances are comparatively much lower than in the Ori. noco (Vásquez 1984 b, Saunders \& Lewis 1988 a). Along shore c, abundance decreased between sites 1-3 and then increased probably because of the rela. tively higher suspended load transported by the Meta River. The lowest transparency $(25 \mathrm{~cm})$ of all studied sites was observed at the mouth of this river.

During this period, rotifers made up the most important group of zooplankton along the water. courses, exhibiting relative abundances between $81.8 \%$ and $97 \%$ (Fig. 6 b). Copepods, scarse between sites 1-6, then showed a slight increase.

\section{b) Dominant species of zooplankton}

In spite of the high number of identified species of rotifers and cladocerans, only 9 taxa of rotifers and 7 species of cladocerans showed at high water densities equal or higher than $10 \%$ (Tables III, IV). Similar observations have been reported for Ama. zon waterbodies where, despite a large number of rotifer species, few are numerically dominant (Robertson \& Hardy 1984). At low water the number of dominant rotifer taxa increased to 14 and that of cladocerans to 8 . In all cases, however, both groups showed a predominance of planktonic or semiplanktonic species among the dominants.

At high water the most frequent dominant rotifer species was Conochilus dossuarius followed by Keratella americana and Polyarthra vulgaris. In this period, dominant bdelloid rotifers showed a certain frequency along the first sites. With regard to cladocerans, the following succession of frequent dominant species was observed: Moina reticulata (sites 1-2), Bosminopsis deitersi (sites 3-9), and Bosmina tubicen (sites 15-21). The rest of dominant cladocerans were present primarily in the Delta.

At low water, dominant rotifer species frequent along the studied section were $K$. americana and Lecane proiecta. Dominant Brachionus falcatus, $C$. dossuarius and P. vulgaris were frequent between sites 1-3, while Ploesoma lenticulare was frequent between sites 3-6. At this period, $B$. deitersi and Moina minuta were dominant and frequent among the cladocerans up to site 6 from where they were replaced by $B$. itubicent.

Rey \& Vásquez (1986 a) characterized whitewater bodies by the species association $M$. minuta, $C$. cornuta, B. tubicen and B. deitersi. Dominant cladoceran assemblage in the Orinoco was similar to the previous characterization. Some of these species or related ones are also dominant in the potamoplankton of others tropical rivers : South America (José de Paggi 1980 and 1981, Robertson \& Hardy 1984). Sri Lanka (Fernando 1980).

The presence of a typical freshwater zooplankton assemblage in sites of the Delta under the influcnce of tides can be explained by the fact that our samples were collected superficially. At high water, relatively little mixture of fresh and marine waters occurs superficially up to a distance of some $70 \mathrm{~km}$ off the Delta coast. At low water, this limit recedes to some $50 \mathrm{~km}$ off the coast. For instance, in May 1987, during the rising-water phase, superficial salinity at $50 \mathrm{~km}$ offshore was $0.2 \%$ (J. Monente, pers. comm.). Egborge (1987) found in the Warri River a limit of salinity for cladocerans below $0.25 \%$, which is a limit that may be found superficially along the coast of the Orinoco Delta.

Among the dominant cladocerans in the Orinoco, a high proportion of egg carrying females was observed at low water along the sampling sites (Table $\mathrm{V}$ a) which suggests that these species may be able to grow and reproduce along the river. This was particularly the case for $B$. tubicen, $B$. deitersi, and $M$. minuta. At high water a large set of egg carrying females was observed mainly restricted to site 5 where cladocerans were abundant (Table $\mathrm{V}$ b). In the 
Table III. Dominant rotifer and cladoceran species at high water (\%):

- : $10-19 ; 0: 20-29 ;{ }^{*}: 30-39:+: 40-49 ;+t:>50$.

Bufluta* Gidel

B. sahriaten grasticie

C. dossuerus

C. Longueca

R. deniricana

1. connuta

L. pracecta

P. vulgaris

I yeacilis

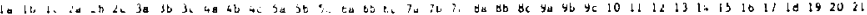
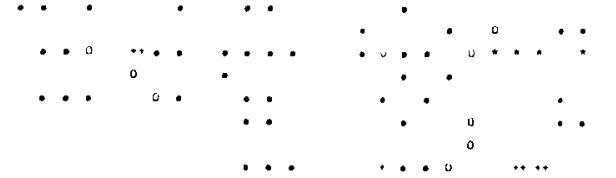

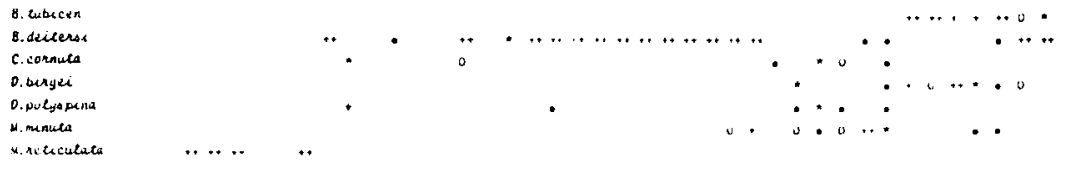

Table' IV. Dominant rotifer and cladoceran species at low water $(\%)$ :

• : 10.19: o: 20-29:* : 30-39; + : 40-49; ++ : >50.

Bdelloida (indet.)

B. budapestinensis

B. calyciflorus

B. falcatus

C. campanulata

c. dossuarius

F. longiseta

H. intermedia

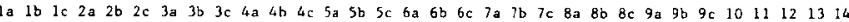

K. americana

L. proiecta

P. Renticulare

P. vulgaris

T. elongata

T. gracilis

B. hagmanni

B. tubicen

B. deitersi

C. connuta

D. birgei

D. spinulosum

H. minuta

W. Eeticulata

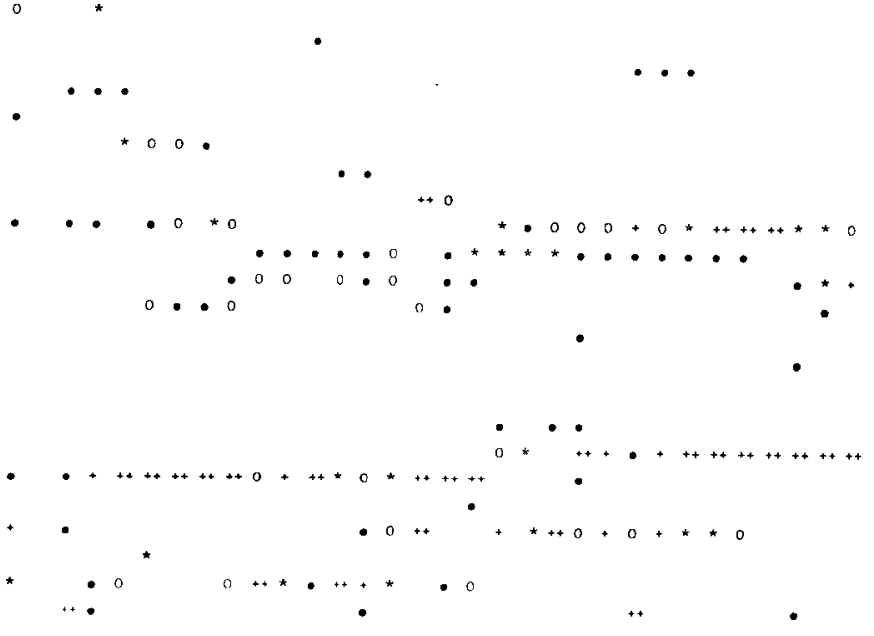


Table V. Percentage of egg carrying cladocerans; a : at low water ; b at high water (dominant species).

\begin{tabular}{|c|c|c|c|c|c|c|c|c|c|c|c|c|c|}
\hline & 1 & 2 & 3 & 4 & 5 & 6 & 7 & 12 & 14 & 15 & 16 & 17 & 19 \\
\hline B. hagmanni & & & & & 25.0 & & & & & & & & \\
\hline B. tubicen & & & & & 27.0 & & & & & 19.0 & 24.0 & 31.0 & 12.5 \\
\hline B. deitersi & & & 27.3 & & 35.0 & 25.5 & 22.0 & & & & & & \\
\hline C. cornuta & & & & & 14.0 & & & & & & & & \\
\hline D. birgei & & & & & & & & & 100 & 19.0 & 19.0 & 21.0 & \\
\hline D. polyspina & & & & 98.0 & 6.7 & & & 100 & & & & & \\
\hline M. minuta & & & & & 14.3 & & 100 & & & & & & 25.0 \\
\hline M. reticulata & 17.3 & 7.1 & & & & & & & & & & & \\
\hline
\end{tabular}

\begin{tabular}{|c|c|c|c|c|c|c|c|c|c|c|c|c|}
\hline & 1 & 2 & 3 & 4 & 5 & 6 & 7 & 8 & 9 & 10 & 12 & 13 \\
\hline B. hagmanni & & & & & 9.1 & & 16.7 & & & & & \\
\hline B. tubicen & 66.7 & 50.0 & 58.3 & 25.0 & 33.3 & 18.8 & 20.0 & 21.9 & 13.6 & 12.8 & 18.5 & 11.0 \\
\hline B. deitersi & 48.3 & 9.2 & 27.8 & 26.5 & 27.7 & 55.3 & 19.2 & & & & & \\
\hline c. cornuta & 14.3 & & & 23.7 & 8.8 & 12.2 & & & & & & \\
\hline D. birgei & 9.9 & & 20.0 & & 11.3 & 9.1 & & 14.5 & 9.3 & & & \\
\hline D. spinulosum & & 52.0 & & & & & & & & & & \\
\hline M. minuta & 39.7 & 17.2 & 10.5 & 24.7 & 28.0 & 23.8 & 20.0 & & & & & \\
\hline M. reticulata & 9.1 & 56.0 & & & 7.9 & & & 8.5 & & & 40.0 & \\
\hline
\end{tabular}

Table VI. Mean number of eggs in ovigerous females (dominant species).

\begin{tabular}{ll}
\hline B. hagmanni & 3.6 \\
B. tubicen & 3.3 \\
B. deitersi & 2.8 \\
C. comuta & 2.6 \\
D. birgei & 2.5 \\
D. polyspina & 2.7 \\
D. spinulosum & 2.0 \\
M. minuta & 2.5 \\
M. reticulata & 2.0 \\
\hline
\end{tabular}

Delta a certain percentage of B. tubicen and D. birgei egg carrying females was also observed during the high water period.
Mean number of eggs carried by ovigerous females is included in Table VI. In general, number of eggs was low (mean : 2.6) with highest values for $B$. hagmanni and $B$. tubicen. This low fertility supports the observations previously noticed for populations of Bosminidae from the mouth of Amazone (Stingelin (1904) and from a floodplain lake of the Orinoco (Rey \& Vásquez 1986 b).

\section{Acknowledgements}

One author (E.V.) thanks Dr. Walter Koste for his continuous collaboration in the identification of rotifers. We also thank Ms. Maria Laura Medina and Mr. Gary Bravo for their most valuable assistance in the field and laboratory work. Dr. Werner Wilbert provided us information on the Orinoco Delta and helped us in the computer elaboration of graphs. 


\section{References}

Andel (T.H. van). 1967, - The Orinocu Delta. J. Sed. Petrol., 37 (2) 297-310.

Arcifa (M.S.). 1984. - Zooplankton composition of ten reservoirs in southern Brazil. Hydrobiologia, $113: 137-145$.

Brandorff (G.O). 1976. - A new species of Bosminopsis (Crustacea, Cladocera) from the Rio Negro. Acta Amazonica, 6: 109-114.

Brandorff (G.O.), Koste (W.) \& Smirnov (N.N.). 1982. - The composition and structure of rotifera and crustacean communities of the Lower Rio Nhamunda, Amazonas, Brazil. Stud. Neol rop. Fauna and Envir. 17:69-121.

Dussart (B.). 1984. - Some Crustacea Copepoda from Venezuela Hydrobiologia, $113: 25.67$.

Egborge (A.B.M.). 1972. - A preliminary check list of zooplankıon organisms of the River Oshum in the Western State of Nigeria. Nig. J. Sci., 6: 67-71

Egborge (A.B.M.). 1987, - Salinity and the distribution of Cladocera in Warti River, Nigeria. Hydrobiologia, 145:159.167.

Fernando (C.H.). 1980. - The freshwater zooplankton of Sri Lanka, with a discussion of tropical freshwater zooplankton composition. Int. Revue ges. Hydrobiol., 65 (1) : 85-125.

Gibbs (A.K.) \& Barron (C.). 1983. - The Guiana Shield reviewed Episodes, 1983 (2): 7.14.

Green (1.). 1962. - Zooplankton of the River Sokoto. The Crustacea. Proc. Zool. Soc. Lond. 138: 415-453.

Hauer (J.). 1956. - Rotatorien aus Venezuela und Kolumbien. Erg. Di. Limnol. Venezuela Exp. 1952, 1:277-312.

Hauer (J.). 1965. - Zur Rotatorienfauna des Amazonasgebietes. Imt. Revtle ges. Hydrobiol, 50 (3) : 34|-389.

Hynes (H.B.N.). 1970. - The Ecology of Running Waters. University of Toronto Press. Toronto.

Infante (A.). 1984, - A note about Daphnia in Venezuelan waterbodies. Hydrobiologia, $119: 81-82$.

José de Paggi (S.). 1978. - First observations on longitudinal succession of zooplankton in the main course of the Paraná River between Santa Fe and Buenos Aires harbour. Stud. Neof rop. Fauna and Environ, 16:185-199.

José de Paggi (S.). 1980. - Campaña limnológica Keratella I en el rio Paraná Medio : zooplankton de ambientes lóticos. Ecolo gia (Argentina) $4:$ 69-75.

José de Paggi (S.). 1981, - Variaciones temporales y distribución horizontal del zooplancton en algunos cauces secundarios del río Paraná Medio. Stud. Neotrop. Fauna and Environ., 16 : 185-199.

José de Paggi (S.). 1983. - Estudio sinóptico del zooplancton de los principales cauces y tributarios del valle aluvial del río Parana : tramo Goya-Diamante, 1 parte. Rev. Asac. Cienc. Nat. Litoral, $14: 163-178$.

José de Paggi (S.) \& Koste (W.). 1988. - Rotifera from Saladillo river basin (Santa Fe province, Argentina). Hydrobiologia, 157 : 13-20.

Korovchinsky (N.M.). 1981 - Taxonomic and faunistic revision of Australian Diaphanosoma (Cladocera, Sididae). Aust. J. mar. Freshwat. Res., $32: 813.831$.

Lewis (W.M.). 1988. - Primary production in the flowing waters of the Orinoco River in relation to its tributaries and floodplain. Ecology, 69: 679-692.

Meade (R.H.), Nordin (C.F.), Pérez Hernandez (D.), Mejia (A.) \& Pérez Godoy (J.M.). 1983, - Sediment and water discharge in Rio Orjnoco, Venezuela and Colombia. Proc. Second Iniemai. Symp. River Sedimentation. Water Resources and Electric Power Press (Beijing, China): 11341144.
Ministerio del Ambiente y de los Recursos Naturales Renovables (M.A.R.N.R.). 1979. - Allas de Venezuela, Direccion de Cartografía Nacional, Caracas, 331 p.

Paggi (J.C.) \& José de Paggi (S.). 1973. - Sobre algunos rotíferos nuevos para la fauna argentina. Rev. Asoc. Cienc. Nat. Lit., 4 : 49-60.

Rey (J.) \& Vásquez (E.). 1986 a. - Cladocères de quelques cours d'eaux du bassin moyen de l'Orénoque (Vénézuela). An $\mathrm{m} / \mathrm{s} \mathrm{Lim}$. nol., 22 (2) : 137-168.

Rey (J.) \& Vásquez (E.). 1986 b. - Bosminopsis macaguensis n. sp. et Alona ovata n. sp. (Crustacea, Cladocera), Cladocères nouveaux du Vénézuela. Annts Limnol., 22 (3): 219.229.

Rey (J.) \& Vásquez (E). 1989. - Bosminopsis brandorffi n. sp. (Crustacea, Cladocera), une nouvelle espece de Bosminidae des systemes Amazone et Orénoque. Ammls Limnol., 25 (3) : à paraître.

Robertson (B.A.) \& Hardy (E.R.). 1984. - Zooplankton of Amazonian lakes and rivers. 337-352. In $\mathrm{H}$. Sioli (Ed.). The Amazon. Limnology and Landscape Ecology of a Mighty Tropical river and IIs Basin. Dordrechı, Junk Publishers, 763 p.

Sánchez (L.), Vásquez (E.) \& Blanco (L.). 1985 - Limnological inves tigation of the Rivers Uracca, Yabo, Morichal Largo, and Claro in the eastern plains of Venezuela. Verh. Intemal. Verein. Lim. nol., $22: 2153-2160$.

Saunders (J.F.) \& Lewis (W.M.). 1988 a. - Zooplankton abundance in the Caura River, Venc7uela. Biorropica, 20 (3): 206-214.

Saunders (J.F.) \& Lewis (W.M.). 1988 b. - Zooplank ton abundance and transport in a tropical white-water river. Hydrobiologia, $162: 147-155$

Saunders (J.F.) \& Lewis (W.M.). 1989. - Zooplankton abundance in the Lower Orinoco River. Venezuela. Limnol. Oceanogr. : In press.

Vásquez (E.). 1984 a. - Estudio de las comunidades de rotiferos de] Orinoco Medio, Bajo Caroni y algunas lagunas de inundación. Mem. Soc. Cienc. Nai. La Salle, 44 (121) : 95-108.

Vásquez (E.). 1984 b. - El zooplancton de la sección baja de un río de aguas negras (río Caroní) y de un embalse hidroeléctrico (Macagua), Venezuela. Mem. Soc. Cienc. Nal. La Salle, 44 (121): 109.129.

Vásquez (E.). 1988. - Morfometría de un conjunto de lagunas de inundación del Bajo Orinoco, Venezuela. Pantepuy, $4: 31+37$.

Vasquez (E.) \& Kosle (W.). 1988. - Form variation of the rotifer Brachionus variabilis (Hempel 1896) from the Orinoco River (Venezuela). Ammis Limmol., 24 (2) : 127-129.

Vásquez (E \& Sánchez (L). 1984. - Variación estacional del plancton en dos sectores del rio Orinoco y una laguna de inundación adyacente. Mem. Soc. Cinc. Nat. La Salle, 44 (121): 11-31.

Vegas-Vilarnibia (T.), Paolini (J.) \& Herrera (R.). 1988. - A physicochemical survey of blackwater rivers from the Orinoco and the Amazon basins in Venezuela. Arch. Hydrobiol., 111 (4) : 491-506.

Weibezahn (F.H.), Vásquez (E.), Zoppi de Roa (E.) \& Rey (J.). 1989. - Bosminopsis negrensis Brandorff 1976 (Cladocera, Bosminidae), en la cuenca del Rio Orinteco, al Sur de Venezuela. Memor. Soc. Cienc. Nat. Ia Salle, 130 : in press.

Welcomme (R.L.). 1985. - River Fisheries. FAO Fish. Tech. Pap., (262): $330 \mathrm{p}$.

Wilbert (W.) 1986. - Warao Herbal Medicine: A Pneumatic Theon of IIIness and Healing. Ph. D. dissertation, University of California, Los Angeles. University Microfilms International, Ann Arbor, $821 \mathrm{p}$. 